\title{
Vincenzo Capizzi
}

\section{International Handbook of Financial Literacy}

(doi: $10.12831 / 88829$ )

Journal of Financial Management, Markets and Institutions (ISSN 2282-717X)

Fascicolo 2, giugno-dicembre 2017

Ente di afferenza:

()

Copyright (c) by Società editrice il Mulino, Bologna. Tutti i diritti sono riservati.

Per altre informazioni si veda https://www.rivisteweb.it

\section{Licenza d'uso}

L'articolo è messo a disposizione dell'utente in licenza per uso esclusivamente privato e personale, senza scopo di lucro e senza fini direttamente o indirettamente commerciali. Salvo quanto espressamente previsto dalla licenza d'uso Rivisteweb, è fatto divieto di riprodurre, trasmettere, distribuire o altrimenti utilizzare l'articolo, per qualsiasi scopo o fine. Tutti i diritti sono riservati. 


\title{
International Handbook of \\ Financial Literacy
}

Editors: Aprea, C., Wuttke, E., Breuer, K.,

Koh, N.K., Davies, P., Greimel-Fuhrmann, B.,

Lopus, J.S., 2016, Springer Singapore

\author{
Vincenzo Capizzi \\ University of Piemonte Orientale
}

\section{Book Review}

Financial literacy, together with financial education, has become a widely discussed and controversial topic not only in academia but also among regulators and policy-makers. The idea that one, if not the most relevant, of the causes of the financial crisis was the inability of investors and borrowers to understand the characteristics of the financial products they were actually buying has become mainstream in recent years. Determining what the real ability of individuals is to deal with financial matters and understanding which programs, if any, can improve their skills, has thus become one of the most investigated fields of research in recent years.

The International Handbook of Financial Literacy contributes to this debate in a significant, profound yet very practical way.

Firstly, it is really a handbook as it systematically covers all the relevant topics of this vast subject; as such, readers can cherry-pick among chapters, sections and country experiences, those that are most useful and relevant for them. Secondly, it is international in scope: authors come from 19 different countries covering most continents, giving a vast and diversified view of what financial literacy is around the globe.

In the eight chapters of Part I (edited by Carmela Aprea) we find the definition of financial literacy and the analysis of topics such as its relationship with education, behavioral finance, comprehension of finance, financial capability, sociology, metacognition, decision making, and social norms.

Part II (edited by Peter Davies) is on the policy context of financial literacy, and contains six chapters. The topics analysed and discussed are essential for policy makers, and several key questions are deliberated: how can they best develop standards and curricula? Should financial education be a separate program or can it be successfully integrated into other educational programs? Is evidence-based policy more successful than normative policy? What are the objectives: to avoid negative events such as over-indebtedness, or to promote financial well-being? Moreover, who should be responsible for these programs, national or local governments, or private institutions? 
The ten chapters of Part III (edited by Bettina Greimel-Fuhrmann and Jane Lopus) deal with the national orientations of financial literacy. How are governments in different countries promoting and facilitating financial literacy? Of course, this depends on political priorities and on the culture and evolution of different nations. More or less importance will be given to the enhancement of financial culture depending on the nation's overall financial situation, the orientations of policy-makers, and the relevance of issues like consumer protection.

Klaus Breuer is the editor of Part IV, which contains six chapters and focusses on the assessment, of financial literacy. Assessing the impact of education programs on financial literacy and behavior and defining which groups in society are at risk and need more protection and education, is essential for the appropriate allocation of resources. This part is technical, dealing with structural equation modelling, analysing a range of instruments such as scales to assess financial literacy, discussing metacognition (how people think and argue), investigating attitudes towards money, and personality.

The seven chapters of Part V (edited by Noi Keng Koh) describe and analyse the instructional interventions for fostering financial literacy. There are different approaches to financial education and they vary significantly across different nations and regions. Being tightly intertwined with economics, mathematics, and computer skills, financial education has better and more effective results when it is embedded in interdisciplinary programs with economics, mathematics, computer science, and sociology. The combination of literacy (knowledge) and capability (application, cases) is essential, the final goal not being the level of knowledge but also the welfare of consumers and investors. Financial literacy requires experience and educational programs in this disciplinary field; several chapters of part $\mathrm{V}$ confirm this orientation and describe different national examples.

Eveline Wuttke is the editor of the five chapters of Part VI, which deals with how the teacher may be taught how to teach financial literacy. Teacher education and competence are essential as most teachers have very little or no experience with financial education and often with finance as such. Teachers' professional competence consists of knowledge, skills, and the ability and motivation to interact and transfer literacy and capability to students. Again, in this regard the importance of practice, actual cases, and the role of gaming is emphasized since finance is not only a cultural topic but a daily experience of everyday life.

In conclusion, the International Handbook of Financial Literacy proves to be a complete and update to date volume, with a broad perspective contribution on this fundamental and very topical subject. Materials, cases and experiences, are reported clearly and thoroughly helping the reader to not only understand the state of the art but also putting him or her in the condition to replicate, change and, hopefully, improve financial experiences. Situations are different across the globe, with every nation having a different approach but also a different cultural context and background; educational systems are also different and the relevance of individual financial choices depends on not only the evolution of the country, but also on the regulatory and legislative approach taken. It is clear that if consumers are free to make their choices they will need more tools and skills compared to situations in which a paternalistic regulator will tell them what to do 
and what not to do. There is no universal recipe to enhance financial literacy but this handbook gives academics and policy-makers, ingredients, proposals and hints that are useful to develop appropriate and well-founded solutions to improve the level of financial competence of people. 
